\title{
Investigation of physical risk factors in Kahramanmaraş Paper Mill
}

\author{
Ahmet Tutuş ${ }^{\mathrm{a}}$, Nevres Demir ${ }^{\mathrm{a}}$, Mustafa Çiçekler ${ }^{\mathrm{a}, *(i), \text { Hasan Serin }}{ }^{\mathrm{a}}$
}

\begin{abstract}
In this study, the hazards and risks that may arise in the paper industry in terms of worker health and work safety are analyzed and precautions were mentioned in order to keep these hazards and risks at acceptable levels. It is intended to give an idea of how risk analysis is implemented in a sector related to forest products in practice, and to provide an example of further work in the field. Kahramanmaraş Paper Mill (KMK) belongs to Kahramanmaraş Paper Industry and Trade Joint Stock Company was chosen as application area. According to No. 6331 Occupational Health and Safety Act, measurements such as gas, temperature, relative humidity, vibration, light intensity, and noise considered important in work environments in terms of occupational health and safety and workers' safety were performed. Measurements were made in approximately 35 different sections of the mill. When obtained results from measurements were compared with the regulations, it was determined that there was no threat to occupational health and safety in terms of noise, temperature, relative humidity, light intensity, gas and vibration. Besides, temperature and relative humidity values were found to be suitable for the mill when assessed according to U.S. ASHRAE standards. It has been also determined that the hand-arm vibration values of the employees are within the desired range. Hydrogen sulfide gas was only encountered in the refining section while the oxygen level in the working fields was sufficient. Sulfur dioxide has not been detected in any sections of the mills. As a result of these assessments, it is concluded that KMK does not carry any risk in terms of occupational health and safety.
\end{abstract}

Keywords: Occupational health and safety, Paper mill, Physical risk factor

\section{Kahramanmaraş Kağıt Fabrikasında fiziksel risk etmenlerinin araştırılması}

\begin{abstract}
Özet: Bu çalışmada, kağıt hamuru ve kağıt sektöründe işçi sağlığı ve güvenliği bakımında meydana gelebilecek risk ve tehlikeler incelenmiş ve bu tehlikeleri ve riskleri kabul edilebilir seviyelerde tutmak için gerekli önlemler belirtilmiştir. Pratikte ormancılık ürünleriyle ilgili bir sektörde risk analizinin nasıl uygulandığı konusunda bir fikir vermek ve bu alanlarda daha ileri çalışmalara örnek olmak amaçlanmıştır. Kahramanmaraş Kağıt Sanayi ve Ticaret Anonim Şirketi'ne bağlı Kahramanmaraş Kağıt Fabrikası (KMK) uygulama alanı olarak seçilmiştir. 6331 sayılı İş Sağlığı ve Güvenliği Kanunu'na göre, iş ortamlarında iş sağlığı ve güvenliği ve işçi güvenliği açısından önemli sayılan gaz, sıcaklık, bağıl nem, titreşim, 1şık yoğunluğu ve gürültü gibi ölçümler yapılmıştır. Bu ölçümler fabrikada 35 farklı kısımlarda uygulanmıştır. Ölçümlerden elde edilen sonuçlar ilgili yönetmeliklerle karşılaştırıldığında, gürültü, sıcaklık, bağıl nem, ışık şiddeti, gaz ve titreşim açısından iş sağlığı ve güvenliği için herhangi bir tehdit oluşturmadığı tespit edilmiştir. Ayrıca, sıcaklık ve bağı nem değerlerinin, ABD ASHRAE standartlarına göre değerlendirildiğinde fabrika için uygun olduğu bulunmuştur. Çalışanların el-kol titreşim değerlerinin arzulanan aralıkta olduğu da tespit edilmiştir. Hidrojen sülfür gazı sadece arıtma bölümünde görülürken, çalışma alanlarındaki oksijen seviyelerini yeterli düzeydedir. Kükürt dioksit fabrikanın herhangi bir bölümünde tespit edilmemiştir. Bu değerlendirmeler sonucunda KMK'nın iş sağlığı ve güvenliği açısından herhangi bir risk taşımadığı sonucuna varılmıştır.
\end{abstract}

Anahtar kelimeler: İşs sağlığı ve güvenliği, Kağıt fabrikası, Fiziksel risk etmenleri

\section{Introduction}

The industrialization movements that started in the $18^{\text {th }}$ century under the influence of the Industrial Revolution started to change and the technological progress gained momentum. The industrial revolution has led to major and fundamental changes in human labor and working conditions and it has played a role in the changing and aggravating working conditions of the working class. Problems related to the health and safety of employees, which are productive factors that are not considered much at the beginning and it has gained importance by putting the working life in the workplace, the yield per labor and the operation into danger. Economic concerns and more unhealthy production environments created by the desire to make production can lead to the loss of life for thousands of people, leading to the emergence of losses (Durgun et al., 2015; Serin et al., 2015; Akyuz et al., 2016). This issue, which emerged as a result of industrialization efforts, has become a problem that concerns the entire working group. This problem, which affects workers and employers from economic, social and psychological aspects, has become a problem for the whole world as well, causing labor, workload losses and economic damages in large dimensions (Aydin, 2012).

Studies have revealed that the problems involving employees' health and safety have no inevitable consequences for production, can be avoided if necessary precautions are taken, rules and laws, including working conditions and conditions in the workplace, must enter into

\footnotetext{
$\triangle$ a Kahramanmaraş Sütçü İmam Üniversitesi, Orman Fakültesi, Orman Endüstri Mühendisliği Bölümü, Kahramanmaraş, Türkiye.

Citation (Atıf): Tutuş, A., Demir, N., Çiçekler, M., Serin, H., 2018. Investigation of physical risk factors in Kahramanmaraş Paper Mill. Turkish Journal of Forestry, 19(3): 330-335. DOI: $\underline{10.18182 / \text { tjf.414136 }}$ 
force. The results of the studies and researches have been approached more scientifically and the concept of worker health and safety has emerged. The necessity of rules and laws involving the working order and conditions in the workplace has arisen. The results of the studies and researches have been approached more scientifically and the concept of "Occupational Health and Safety" has emerged (Gulsen, 2004; Aydin, 2012).

Work factors such as physical, mechanical and environmental factors are important risk factors related to occupational accident occurrence. However, organizational factors play an important role not only in the occurrence of unsafe behaviors, but also in other risk factors (Durgun et al., 2014; Akyuz et al., 2018) A risk assessment is organized review of the risks created by a company's operations and the determination of the likelihood that people will cause injury or illness. This assessment considers current control measures and determines whether additional measures need to be taken.

Appropriate and adequate risk assessment involves determining the significant risks arising from work. This means focusing on the possible risks that may arise from work activity. Trivial risks can often be ignored, and as long as work activity does not worsen these risks, there may be risks that are generally associated with life-related routine activities (eg tripping over a kerb) (Barber et al., 2008; Serin and Tutus, 2008).

Because risk assessment is basic to many safety and health concerns in paper mills, it is an impressive manner of advancing health and safety performance. Additionally, mills are initiating to realize that impressive authority of health and safety risks is identical from the sound management methods related to quality and business greatness. Some companies have found that the introduction of risk reduction control precautions has been cost effective and even favorable for company (Barber et al., 2008).

Implementation of occupational health and safety practices in Paper Mills with high risk factor for work safety and health will provide privilege in some markets and improve working and safety conditions of employees. It will increase the productivity of the motivated employees and affect the quality of the produced product in a great amount.

According to Confederation of Paper Industries (PABIAC, 2015), the weaknesses the paper mills in terms of risks are summarized as follows; integrated approach (inadequate management arrangements needed to support the risk assessment process), targeting (there are insufficient focus on the most serious risks), standards and best practice (persons not the standard to be applied when using it conducted many risk assessments), control measures, residual risk (there are inadequate links to safe systems of work and training needs where residual risks remained), evaluation (some paper mills have not evaluated the control measures).

The aim of this study was to indicate the negativities which cause problems in terms of occupational health and safety in Paper Mills and to make noise, lighting, indoor temperature and gases, relative humidity, hand-arm vibration measurements at Kahramanmaraş Paper Mill, which can be a problem in terms of occupational health and safety to be evaluated. The results of these measurements and analyzes were evaluated taking into account the Law on Occupational Health and Safety No. 6331. It is also our goal that this work constitutes an example for other Forest Industry branches.

\section{Material and methods}

The measurements were made in scrap yard, pulp preparation unit, paper machine 1 (PM1) and paper machine 2 (PM2), laboratory, dining hall, workshops (mechanical maintenance and electricity), administrative building, refinement, offices, turbines and boiler (35 sections) of the Kahramanmaraş Paper Mill.

\subsection{Gas measurements}

Measurements were made in accordance with the "Regulation on Health and Safety Precautions in Chemical Material Work". Nitrogen dioxide- $\mathrm{NO}_{2}$, sulfur dioxide- $\mathrm{SO}_{2}$, oxygen- $\mathrm{O}_{2}$ and hydrogen sulphide- $\mathrm{H}_{2} \mathrm{~S}$ gases were measured. The measurement of nitrogen dioxide- $\mathrm{NO}_{2}$, sulfur dioxide- $\mathrm{SO}_{2}$, and oxygen- $\mathrm{O}_{2}$ gas was carried out using the VENTIS MX4 Multi Gas Monitor and hydrogen sulphide$\mathrm{H}_{2} \mathrm{~S}$ gas was calculated in ppm with TANGO TX1. The model Ventis MX4 complies with relevant provisions of European ATEX directive 94/9/EC and EMC directive 2004/108/EC.

\subsection{Noise measurements}

Noise measurements were carried out in accordance TSE EN ISO 9612. "RadioShack Sound Level Meter" was used for measurements. Five replicates were performed for each section and it took three minutes. To avoid ant reflection during measurements, they were taken at a distance of $1.5 \mathrm{~m}$ from the floor and at a distance of $1 \mathrm{~m}$ from the person performing the measurement, and measurements were made at the operating temperature range $\left(25^{\circ} \mathrm{C}\right)$ of the device.

\subsection{Light intensity measurements}

The measurements were carried out in accordance with TS EN 12464-1: 2004. This standard specifies requirements for lighting solutions for most indoor work places and their associated areas in terms of quantity and quality of illumination. In addition recommendations are given for good lighting practice. Measurements were made with the Extech Instruments (USA)-SDL400 Light Intensity Measuring and Recording Device. The measurement results were determined and recorded in Lux, the unit of light intensity. Measurements were made in accordance with the working environment of the lux meter (operating temperature $23{ }^{\circ} \mathrm{C} \pm 5{ }^{\circ} \mathrm{C}$ ). It was made at different points away from the light reflecting materials and shadow. Measurements were made in four different points and carried out during daytime.

\subsection{Temperature and relative humidity measurements}

Thermal comfort has an important role for employees and their productivity. Thermal comfort describes a person's state of mind in terms of whether they feel too hot or too cold. Relative humidity is the amount of water vapor (vapor pressure) that is in the air. It is a percentage of how much 
moisture the air could possibly hold. The temperature and relative humidity measurements were carried out in accordance with TS EN ISO 27243 by a Homemaxx thermometer.

\subsection{Vibration measurements}

The measurements were carried out in accordance with the ISO 5349-1: 2001 and ISO 5349-2: 2001. The human body, like other physical beings on earth, responds to some vibrational excitation frequencies more in concert than others. It is believed that at these frequencies, man is most receptive to maximum energy transfer from the vibrating source. For this reason, it is potentially harmful health and safety factors would most likely occur at these frequencies.

Hand-arm vibration measurements were carried out in accordance with EN ISO 5349-1 and EN ISO 5349-2 (Regulation on Protection of Employees from Vibration Risk) with the Brüel\&Kjaer 4447 vibration measuring instrument.

\section{Results and discussions}

\subsection{Gas measurements}

Hydrogen sulphide $\left(\mathrm{H}_{2} \mathrm{~S}\right)$ gas was not found in other sections except the refining section. The amount of the $\mathrm{H}_{2} \mathrm{~S}$ in the refining section was determined as $8 \mathrm{ppm}$. According to No. 6331 Occupational Health and Safety Act (OHSA), the maximum $\mathrm{H}_{2} \mathrm{~S}$ amount has to be $10 \mathrm{ppm}$ or $15 \mathrm{mg} / \mathrm{m}^{3}$. This amount ( $8 \mathrm{ppm})$ obtained in the Kahramanmaraş Paper Mill (KMK) does not constitute a risk to the business in terms of occupational health and safety.

Nitrogen dioxide $\left(\mathrm{NO}_{2}\right)$ gas was measured in the refining section as $5 \mathrm{ppm}$. In addition, it was found in the PM2 vacuum pump section and the amount was found to be $1 \mathrm{ppm}$. According to OHSA, This value should not exceed 5 ppm. The $\mathrm{NO}_{2}$ gas amount in refining section was at the limit value and should be reduced for worker health while PM2 section does not constitute any risk.

Sulfur dioxide $\left(\mathrm{SO}_{2}\right)$ gas has not been found anywhere in KMK and The oxygen level of KMK was found within the limit values that are considered ideal in terms of worker health and safety.

\subsection{Noise measurements}

The findings of 35 different points' measurements were presented in Table 1. According to these results, the noise level in $57 \%$ of the measurement points is above $85 \mathrm{~dB}(\mathrm{~A})$, which can be accepted under the working conditions of 8 hours of ILO working conditions. The highest noise values were measured at PM2 press (99.1 dB(A)), PM2 vacuum pump (98.4 dB(A)), PM2 coil cut (98.6 dB(A)), PM1 sieve (97.8 dB(A)), PM1 press (97.2 dB(A)), PM1 coil cut (96.9 $\mathrm{dB}(\mathrm{A}))$, and $\mathrm{PM} 2$ sieve $(96.5 \mathrm{~dB}(\mathrm{~A}))$.

On the other hand; office $(66.4 \mathrm{~dB}(\mathrm{~A}))$, laboratory $(67.2$ $\mathrm{dB}(\mathrm{A}))$, administrative building $(56.4 \mathrm{~dB})$, stockroom $(58.4$ $\mathrm{dB})$ electrical workshop $(68 \mathrm{~dB}(\mathrm{~A}))$ is the points at where the lowest noise levels are measured.

The mean noise level of the same mill was measured as $90.8 \mathrm{~dB}$ (A) in the study conducted by Serin and Tutus (2008), while the mean noise level in this study was calculated as $85.1 \mathrm{~dB}(\mathrm{~A})$. It is a sign that management was taking precautions to prevent from noise. However, it is understood that the noise from the other side cannot be reduced further due to the machine and working principle. Personal protective equipment must be used or working hours should be arranged in these areas.

\subsection{Light intensity measurements}

It has been determined that refining (3600 lux), scrap yard (3150 lux), new pulp preparation (896.6 lux) and pulper (295 lux) sections have the highest light intensity and PM1 coil winder (31 lux), PM1 vacuum pump (7.6 lux), PM2 dryer (10.3 lux), dryers control room (12.6 lux), PM vacuum pump (19 lux) have the lowest light intensity in the mill.

According to TS EN 12464-1: 2013; TS EN 124641.2011: 2012 standards, the minimum light intensity must be 200 lux in paper mills. There are only five sections that are over 200 lux in the mill. The first one is the refining section (3600 lux) and the second one is the scrap yard (3150 lux). However, since these parts are not in the closed environment, they are in the natural lighting area, so the light intensities are higher. Apart from these sections, new pulp preparation (896.8 lux), pulper (295 lux) and mechanical maintenance workshop (231 lux) sections have the highest light intensity. According to the same standards, the minimum light intensity in laboratories must be 300 lux. This value was found as 135.3 lux in the mill laboratory. This result indicates that the mill does not provide adequate light in the laboratory. Besides, the light intensity must be 300 lux in paper mill offices according to mentioned standards. As a result of the measurements, the light intensity levels of the offices have been found to be 153.6 lux. In addition, it has been determined that the enlightenment cannot be achieved in the majority of the mill.

Light intensity level is an important parameter for OHS for enterprises and if adequate precautions and improvements are not taken, accidents will be inevitable. In order to make more use of natural daylight, roof and window systems must be rearranged or artificial lighting should be used to provide minimum light intensity according to TS EN 12464-1.2011 standards.

\subsection{Temperature and relative humidity measurements}

It has seen that relative humidity is $30 \%$ or more in 19 sections of the mill. Since the amount of relative humidity that must be present in mills must be within the range of 30 $70 \%$, the amount of relative humidity in most parts of the mill is the desired level.

As shown in Table 1, temperatures in the mill range from $14-22{ }^{\circ} \mathrm{C}$. Temperature values are within the ideal working limit at $37.2 \%$ of the mill. According to US ASHRAE standards, Temperature and relative humidity must be between $20-25.5{ }^{\circ} \mathrm{C}$ and $30-60 \%$, respectively. Some of the factors affecting thermal comfort in the working environment are the body surface area and the clothes. Daily activities also affect the thermal comfort. Body temperature changes during sitting and standing (ASHRAE, 2001; Ongel and Mergen, 2009). 
Table 1. Findings of noise, light intensity, temperature, relative humidity and gas measurements in Kahramanmaraş Paper Mill

\begin{tabular}{|c|c|c|c|c|c|c|c|c|}
\hline Sections & $\begin{array}{l}\text { Noise } \\
(\mathrm{dBA})\end{array}$ & $\begin{array}{l}\text { Light } \\
\text { (lux) }\end{array}$ & $\begin{array}{l}\text { Temp. } \\
\left({ }^{\circ} \mathrm{C}\right)\end{array}$ & $\begin{array}{l}\text { R. Hum. } \\
(\%)\end{array}$ & $\begin{array}{c}\mathrm{H}_{2} \mathrm{~S} \\
(\mathrm{ppm})\end{array}$ & $\begin{array}{c}\mathrm{NO}_{2} \\
(\mathrm{ppm})\end{array}$ & $\begin{array}{c}\mathrm{SO}_{2} \\
(\mathrm{ppm})\end{array}$ & $\begin{array}{l}\mathrm{O}_{2} \\
(\%)\end{array}$ \\
\hline Scrap yard & 77.3 & 3150 & 16 & 22 & 0 & 0 & 0 & 20.5 \\
\hline Pulper & 82.8 & 295 & 20 & 32 & 0 & 0 & 0 & 20.9 \\
\hline Old pulp preparation & 87.2 & 150 & 18 & 30 & 0 & 0 & 0 & 21.1 \\
\hline New pulp preparation & 92.9 & 897 & 20 & 30 & 0 & 0 & 0 & 21.1 \\
\hline Pulp preparation control room & 79.7 & 127 & 22 & 28 & 0 & 0 & 0 & 21.1 \\
\hline PM1 vacuum pump & 91.3 & 8 & 18 & 22 & 0 & 0 & 0 & 20.9 \\
\hline PM1 sieve & 97.8 & 16 & 16 & 34 & 0 & 0 & 0 & 20.9 \\
\hline PM1 press & 97.2 & 52 & 20 & 30 & 0 & 0 & 0 & 20.5 \\
\hline PM1 dryers & 90.6 & 42 & 17 & 56 & 0 & 0 & 0 & 20.9 \\
\hline PM1 size press & 92.8 & 38 & 20 & 30 & 0 & 0 & 0 & 20.9 \\
\hline PM1 coil winder & 93.2 & 31 & 20 & 30 & 0 & 0 & 0 & 21.1 \\
\hline Free field (coil winder) & 93.8 & 45 & 20 & 32 & 0 & 0 & 0 & 21.1 \\
\hline PM1 coil cut & 96.9 & 73 & 18 & 28 & 0 & 0 & 0 & 21.1 \\
\hline Sieve control room & 90.6 & 135 & 22 & 28 & 0 & 0 & 0 & 21.1 \\
\hline Free field (dryers) & 91.8 & 90 & 20 & 32 & 0 & 0 & 0 & 21.3 \\
\hline PM2 vacuum pump & 98.4 & 19 & 15 & 26 & 0 & 1 & 0 & 20.9 \\
\hline PM2 sieve & 96.5 & 34 & 18 & 26 & 0 & 0 & 0 & 20.9 \\
\hline PM2 press & 99.1 & 48 & 16 & 32 & 0 & 0 & 0 & 20.9 \\
\hline PM2 dryers & 91.8 & 10 & 14 & 52 & 0 & 0 & 0 & 20.9 \\
\hline PM2 size press & 91.5 & 45 & 17 & 30 & 0 & 0 & 0 & 20.9 \\
\hline PM2 coil winder & 93.5 & 42 & 17 & 28 & 0 & 0 & 0 & 21.1 \\
\hline PM2 coil cut & 98.6 & 68 & 15 & 30 & 0 & 0 & 0 & 21.1 \\
\hline Dryers control room & 73.8 & 13 & 17 & 41 & 0 & 0 & 0 & 21.3 \\
\hline Stockroom & 58.4 & 83 & 18 & 30 & 0 & 0 & 0 & 21.3 \\
\hline Free field (stockroom) & 71.6 & 18 & 16 & 30 & 0 & 0 & 0 & 21.1 \\
\hline Technical offices & 61.6 & 62 & 17 & 29 & 0 & 0 & 0 & 20.9 \\
\hline Laboratory & 67.2 & 135 & 17 & 32 & 0 & 0 & 0 & 20.9 \\
\hline Workshop (mech. maintenance) & 82.6 & 231 & 18 & 32 & 0 & 0 & 0 & 20.9 \\
\hline Workshop (electricity) & 68.0 & 192 & 20 & 30 & 0 & 0 & 0 & 20.9 \\
\hline Dining hall & 74.0 & 124 & 20 & 34 & 0 & 0 & 0 & 20.9 \\
\hline Administrative building & 56.4 & 76 & 22 & 30 & 0 & 0 & 0 & 23.1 \\
\hline Refining & 85.0 & 3600 & 16 & 22 & 8 & 5 & 0 & 20.9 \\
\hline Boiler (Power Plant) & 94.3 & 108 & 20 & 30 & 0 & 0 & 0 & 20.9 \\
\hline Turbine (Power Plant) & 93.6 & 29 & 18 & 26 & 0 & 0 & 0 & 20.9 \\
\hline Office (Power Plant) & 66.7 & 154 & 14 & 26 & 0 & 0 & 0 & 20.9 \\
\hline
\end{tabular}

\subsection{Vibration measurements}

Seven sections where the workers were exposed to vibration were determined and hand-arm vibrations were measured at these points. It has been determined that the vibration values of the six sections are suitable in accordance with the "Regulation on the Protection of Employees from Vibration-Related Risks".

In this regulation (MLSS, 2013a);

Daily exposure limit value for eight hours of working is $5 \mathrm{~m} / \mathrm{s}^{2}$.

Daily exposure action value for eight hours of working is $2.5 \mathrm{~m} / \mathrm{s}^{2}$.

The findings obtained from hand-arm vibration measurements were given in Table 2. And it has seen that six measured points have suitable values for working environment according to the related regulation and do not present any danger.

Table 2. The findings obtained from hand-arm vibration measurements

\begin{tabular}{lc}
\hline Sections & Hand-arm vibration $\left(\mathrm{m} / \mathrm{s}^{2}\right)$ \\
\hline Pulper & 2.13 \\
Cleaner & 2.05 \\
Sand catcher & 5.21 \\
Starch preparation tank & 2.31 \\
PM2 vacuum pomp & 1.91 \\
Power plant & 2.12 \\
Turbine & 1.41 \\
\hline
\end{tabular}

The maximum vibration $\left(5.21 \mathrm{~m} / \mathrm{s}^{2}\right)$ has been measured in the sand retainers. In this section, it is considered that high vibration measurement value is caused by the working principle of the machine. The lowest vibration $\left(1.41 \mathrm{~m} / \mathrm{s}^{2}\right)$ value has been determined in the turbine.

\section{Conclusions}

Measurements of important parameters such as noise, light intensity, temperature, relative humidity, vibration, and indoor gases related with the health and safety of working technical personnel and workers were made and possible risks and precautions that can be taken are stated.

As a result of the measurements, the average noise level of the mill was determined as $85 \mathrm{~dB}(\mathrm{~A})$. This value is less than the exposure limit of $87 \mathrm{~dB}(\mathrm{~A})$ specified in the "Regulation on the Protection of Employees from Risks Related to Noise" (MLSS, 2013b). However, the noise levels at 20 points measured are above $85 \mathrm{~dB}(\mathrm{~A})$. The noisiest part of the operator is the PM2 press part. Compartments can be used to control the passage of noise and the spaces between the materials used in these compartments must be filled or covered with sound absorbing materials (Serin and Tutus, 2008). Maintenance, revision and insulation should be done for the machines which are noise sources. Personal protective equipment must be provided, its use widespread and encouraged. 
Alternate working hours should be adjusted so that workers are less affected by noise.

When the light intensity measurements were examined, the average light intensity level of the mill was found to be 207.92 lux. According to related regulation, the mill's light intensity measurement results are at the desired level in only 5 sections (200 lux) (MLSS, 2013c). It is important that the mill keep the light intensity values at the level specified in the regulation. Therefore; sections with low lighting levels should be equipped with high-lighting capacity lamps. Light corridors must be built into the building and downstairs from the factory roof in order to make more use of the sunlight (Serin and Tutus, 2008). The design and layout of the machines should be done in such a way as not to hinder the utilization of sunlight for lighting purposes. Doors, windows, machines and benches should be positioned to benefit more from daylight.

It is seen that relative humidity is $30 \%$ or more in 19 sections of the mill. Since the amount of relative humidity that must be present in the mill must be within the range of $30-70 \%$, the amount of relative humidity in most parts of the mill is the desired level. The temperature is $20-25.5^{\circ} \mathrm{C}$ for ideal conditions under US ASHRAE standards (ASHRAE, 2001). Based on US ASHRAE standards, it has been determined that the mill has the right temperature for the working environment.

As a result of hand-arm vibration measurement at mill, it was found that the maximum vibration was spread from sand holders at $5.21 \mathrm{~m} / \mathrm{s}^{2}$. It is determined that the vibration value is high in this part in view of the working principle of the machine. The ergonomically designed suitable work equipment should be selected which will produce the lowest possible vibration in order to reduce the effect of vibration. Suitable maintenance programs should be implemented for workplace, workplace systems and work equipment. Workplace and working environment should be designed and organized accordingly. The necessary knowledge and training to use work equipment correctly and safely in order to reduce mechanical vibrational exposures should be given to workers. Adequate rest periods and working hours should be arranged (MLSS, 2013a).

When the indoor gases (hydrogen sulphide, nitrogen dioxide, sulfur dioxide, oxygen) measurements were evaluated; hydrogen sulphide gas was not found in other sections except the refining section. The amount of hydrogen sulphide in this section was determined to be 8 $\mathrm{ppm}$. Since the maximum value of hydrogen sulphide gas is $10 \mathrm{ppm}$ or $15 \mathrm{mg} / \mathrm{m}^{3}$, this value does not constitute a risk to the health of the worker in terms of health and safety. In the refining section, nitrogen dioxide gas was measured at 5 $\mathrm{ppm}$. At the same time, nitrogen dioxide gas was found in the PM2 vacuum pump section (1 ppm). The maximum value of the nitrogen dioxide gas is $5 \mathrm{ppm}$ (MLSS, 2013d).Hazardous chemical substances must be used by minimum number of workers in order to reduce nitrogen dioxide gas in the mill. The amount of chemicals that must be used in the mill must be kept to a minimum. The necessary arrangements must be made for proper handling, transport and storage of hazardous chemical substances. By substitution, chemicals that are safe or less dangerous for the health and safety of workers can be used instead of hazardous chemicals.

\section{Acknowledgement}

This research was supported by the Kahramanmaraş Sütçü İmam University, Research Project Coordination Unit; under project number 2013/6-19 YLS.

\section{References}

Akyuz, K.C., Yildirim, I., Tugay, T., Akyuz, I., Gedik, T., 2016. Work accidents in forest products industry sector general overview of statistics. Journal of Forestry, 12(2): 66-79.

Akyuz, K.C., Yildirim, I., Gungor, C., 2018. Validation of a pre-existing safety climate scale for the Turkish furniture manufacturing industry. International Journal of Occupational Safety and Ergonomics (JOSE), 1-9.

ASHRAE, 2001. Standard 62-Ventilation for Acceptable Indoor Air Quality, American Society of Heating, Refrigerating and Air-Conditioning Engineers, Atlanta.

Aydin, E., 2012. Implementation of occupational health and safety management systems in automotive subsidiary industries. Master's Thesis, Kocaeli University, Graduate School of Natural and Applied Sciences, Kocaeli.

Barber, A., Timms, A., Hawkins, S., Pimblet, D., Sutton, B., Kingman, M., 2008. Guide to Managing Health and Safety in Paper Mills. Health and Safety Commission, Paper and Board Industry Advisory Committee, HSE Books, ISBN 0717612872.

Durgun, M., Serin, H., Sahin, Y., 2015. Palet production workers' work environment and occupational accidents. SDU Journal of Engineering Sciences and Design, 3(3):545-548.

Durgun, M., Sahin, Y., Serin, H., 2014. Working conditions and work accidents of Laurel collectors. II. National Mediterranean Forest and Environment Symposium, 2224 October, Isparta .... pp. 619-623.

Gulsen, H., 2004. Evaluating the concept of occupational health and safety in the light of developments in the world. TISK Employer Journal, 42: 7-29.

ISO 5349-1, 2001. Mechanical vibration - Measurement and evaluation of human exposure to hand-transmitted vibration -Part 1: General requirements.

ISO 5349-2, 2001. Mechanical vibration - Measurement and evaluation of human exposure to hand-transmitted vibration -Part 2: Practical guidance for measurement at the workplace.

MLSS, 2013a. Regulation on Protection of Employees from Vibration Risk, Ministry of Labour and Social Security of the Republic of Turkey, Official Gazette, No:28743, Accessed: 22.08.2013.

MLSS, 2013b. Regulation on Protection of Employees from Noise Risk, Ministry of Labour and Social Security of the Republic of Turkey, Official Gazette, No:28721, Accessed: 28.07.2013.

MLSS, 2013c. General Lighting Regulations, Ministry of Labour and Social Security of the Republic of Turkey, Official Gazette, No:28720, Accessed: 28.07.2013. 
MLSS, 2013d. Regulation on Health and Safety Precautions in Working with Chemical Matters, Ministry of Labour and Social Security of the Republic of Turkey, Official Gazette, No:28733, Accessed: 12.08.2013.

Ongel, K., Mergen, H., 2009. Review of literature about the effects of thermal comfort parameters on human body. Medical Journal of Süleyman Demirel University, 16(1): 21-25.

PABIAC, 2015. Risk assessment in paper mill, Pabiac Bulletin No:9.

Serin, H., Tutus, A., 2008. Noise and light intensity level analysis in paper mill. $14^{\text {th }}$ National Ergonomics Congress, vol:1, pp: 204-210, 30 October- 1 November, Trabzon.
Serin, H., Sahin, Y., Durgun, M., Simsek, A., 2015. A research on work accidents at manufacturing sector with regard to physical environment conditions. 14th International Scientific Conference of the RomanianGerman University of Sibiu, pp. 358-366, 30-31 October, Sibiu.

TS EN 12464-1, 2004. Light and lighting-Lighting of work places - Part 1: Indoor work places.

TS EN ISO 27243, 2002. Moderate thermal environmentsDetermination of the PMV and PPD indices and specification of the conditions for thermal comfort.

TSE EN ISO 9612, 2009. Determination of acousticaloccupational noise exposure-Engineering Method. 